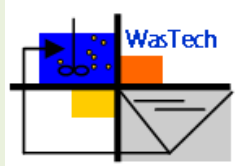

Waste Technology (WasTech)

Journal homepage: http://www.waste.web.id/index.php/wt

An International Journal

\title{
Challenges for municipal solid waste management practices in Vietnam
}

\author{
Nguyen Duc Luong(1,*), Hoang Minh Giang(1), Bui Xuan Thanh(2), Nguyen The Hung(3)
}

(1) Department of Environmental Technology and Management, National University of Civil Engineering (NUCE), Vietnam

(2) Faculty of Environment, Ho Chi Minh City University of Technology (HCMUT), Vietnam

(3) Hanoi Urban Environment One Member Limited Company, Vietnam

$\left({ }^{*}\right)$ Corresponding author: Nguyen Duc Luong, Department of Environmental Technology and Management, National University of Civil Engineering (NUCE), 55 Giai Phong Road, Hai Ba Trung District, Hanoi, Vietnam. Tel: +84-4-36284930, Fax: +84-4-38693714, E-mail: ndluong0711@gmail.com.

\begin{abstract}
Municipal solid waste (MSW) management is currently one of the major environmental problems facing by Vietnam. Improper management of MSW has caused adverse impacts on the environment, community health, and socialeconomic development. This study attempts to provide a review of the generation and characterization, disposal and treatment technologies of MSW to evaluate the current status and identify the problems of MSW management practices in Vietnam. Finally, this study is concluded with fruitful recommendations which may be useful in encouraging the responsible agencies to work towards the further improvement of the existing MSW management system.
\end{abstract}

Keywords - Municipal solid waste; open dumping; landfill; composting; incineration; recycling; Vietnam

Doi: http://dx.doi.org/10.12777/wastech.1.1.2013.17-21

Citation: Luong, N.D., Giang, H.M., Thanh, B.X. and Hung, N.T. 2013. Challenges for municipal solid waste management practices in Vietnam. Waste Technology 1(1):6-9. Doi: http://dx.doi.org/10.12777/wastech.1.1.2013.17-21

\section{Introduction}

Generation of solid waste is a natural consequence of human life. In the recent years, the rapid urbanization and industrialization in Vietnam has led to the migration of people from rural areas to urban areas, which generate thousands of tons of municipal solid waste (MSW) daily. The MSW quantity is expected to significantly increase in the coming years as the country strives to attain an industrialized nation status by the year 2020. The management of MSW is going through a critical phase, due to the lack of suitable facilities for the collection, transportation, treatment and disposal of the larger quantity of MSW generated daily in urban areas (Thanh et al., 2010; Thanh et al., 2011). The improper disposal causes an adverse impact on all components of the environment and human health. Therefore, MSW management is one of the most important environmental problems of Vietnam.

In general, MSW is currently disposed of at open dumping sites and landfills in which many of them are unsanitary landfills without taking any precautions or operational controls. MSW management involves activities associated with generation, storage, collection, transfer and transport, processing and disposal of solid wastes. But, in most Vietnamese urban areas, the MSW management system comprises only four activities including waste generation, collection, transportation, and disposal. Although the collection activity has received the increasing attention from the relating agencies and government, however, due to the significantly increasing quantity of MSW and the limited collection capability in terms of equipments and staffs, the collection efficiency is not really high as expected. In addition, because of the limited public awareness and the lack of investment in infrastructure, the uncontrolled disposal of a large quantity of wastes to the surrounding living areas is still common and the practice of waste separation at sources is not applied. People tend to throw out serviceable goods simply as they are old or outdated and there is no additional cost for their discard. The management of MSW requires proper infrastructure, maintenance and upgrade for all activities. This becomes increasingly expensive and complex due to the continuous and unplanned growth of urban areas. The difficulty in providing the desired level of public service in service in the urban areas is often attributed to the lack of financial and human resources of the responsible agencies. This study aims at providing a review of MSW management practices 
to evaluate the current status and identify the problems of MSW management in Vietnam. This will encourage the responsible agencies to work towards the further improvement of the existing MSW management system through suggestions and recommendations.

\section{Generation and characterization of MSW}

The continuously significant increase in the per capita generation rate and total quantity of MSW during the period 2007-2010 are shown in Table 1. This puts a strain on the existing MSW management system. The average increasing rate of MSW in urban areas is $10-16 \%$ per year. The highest per capita generation rate is observed in the biggest cities such as Ha Noi and Ho Chi Minh. This may be due to the high living standards, the significantly changing life styles, the rapid economic growth, and the high level of urbanization in these cities. It has been know that the quantity of MSW generated depends on a number of factors such as food habits, standard of living, and degree of commercial activities. On average, the consumed amounts of energy, goods, and food of urban residents are about 2-3 times higher than those of rural residents in Vietnam.

There are many categories of MSW such as food waste, rubbish, commercial waste, institutional waste, street sweeping waste, construction and demolition waste, and sanitation waste. MSW contains recyclables (paper, plastic, glass, metals, etc.), toxic substances (paints, pesticides, used batteries), and compostable organic matter (fruit and vegetable peels, food waste). Recently, the composition of MSW has become more diversified. It mainly consists of a large organic fraction (56-77\%), followed by recyclables such as plastic $(10-14 \%)$ and paper $(2-7 \%)$ as shown in Table 2 . This suggests that there is a large potential for the implementation of biological processing and recycling activities for MSW in Vietnam.

Table 1. Generated MSW quantity in Vietnam during 2007 - 2010 (MONRE, 2011)

\begin{tabular}{lccccc}
\hline \multirow{2}{*}{ Content } & \multirow{2}{*}{ Unit } & \multicolumn{3}{c}{ Year } \\
\cline { 3 - 6 } & & $\mathbf{2 0 0 7}$ & $\mathbf{2 0 0 8}$ & $\mathbf{2 0 0 9}$ & $\mathbf{2 0 1 0}$ \\
\hline Urban population & million & 23.80 & 27.70 & 25.50 & 26.22 \\
$\begin{array}{l}\text { Proportion of urban population } \\
\text { country population }\end{array}$ & $\%$ & 28.20 & 28.99 & 29.74 & 30.20 \\
$\begin{array}{l}\text { Per capita generation rate } \\
\text { Total generated quantity }\end{array}$ & kg/day & 0.75 & 0.85 & 0.95 & 1.00 \\
\hline
\end{tabular}

Table 2. MSW composition (\%) at landfills in big cities in Vietnam (MONRE, 2011)

\begin{tabular}{|c|c|c|c|c|c|}
\hline Composition & Ha Noi & Hai Phong & Hue & Da Nang & Ho Chi Minh \\
\hline Organic waste & 57.30 & 56.37 & 77.10 & 68.47 & 63.67 \\
\hline Paper & 5.95 & 4.98 & 1.92 & 5.07 & 7.34 \\
\hline Textile & 3.79 & 4.85 & 2.80 & 1.55 & 2.99 \\
\hline Wood & 4.57 & 4.32 & 0.59 & 2.79 & 4.39 \\
\hline Plastic & 10.96 & 12.81 & 12.47 & 11.36 & 14.19 \\
\hline Leather and rubber & 0.18 & 1.48 & 0.28 & 0.23 & 0.69 \\
\hline Metal & 0.56 & 0.36 & 0.40 & 1.45 & 0.48 \\
\hline Glass & 3.47 & 1.52 & 0.39 & 0.14 & 0.63 \\
\hline Porcelain & 0.82 & 0.86 & 0.79 & 0.79 & 0.76 \\
\hline Soil and sand & 5.86 & 3.02 & 1.70 & 6.75 & 1.84 \\
\hline Coal slag & 2.72 & 5.88 & 0.00 & 0.00 & 0.42 \\
\hline Hazardous waste & 0.49 & 0.05 & 0.00 & 0.02 & 0.04 \\
\hline Sludge & 2.98 & 2.15 & 1.46 & 1.35 & 2.41 \\
\hline Others & 0.31 & 2.50 & 0.00 & 0.03 & 0.09 \\
\hline Total & 100 & 100 & 100 & 100 & 100 \\
\hline
\end{tabular}

\section{Environmental, health, and social-economic impacts of MSW}

Inappropriate management of MSW including the improper treatment and disposal of MSW is the primary cause for environmental pollution and community health impact. In addition, increasing MSW generation also causes the impacts to social-economic development.

\subsection{Environmental impacts}

In Vietnam, practice of waste separation at sources is not yet applied. Moreover, the majority of collection facilities has not met the technical standard and has not ensured the requirement for environmental sanitation. There has not been investment for construction of transferring areas and the number of transport vehicles has not met the increasing demand for daily transport of MSW. This leads to the accumulation of MSW in residential areas causing the odor problem. Generally, all of steps in MSW 
management system including collection, transportation, treatment and disposal are more or less causing environmental pollution. For example, due to the lack of collection, MSW is thrown to the channels, lakes, rivers which results in the degradation of water quality. In addition, the landfill leachate is the other important source of water pollution as well as soil pollution since no landfill leachate treatment methods have been applied at most of dumping and landfill sites. On the other hand, at many open dumping sites, the uncontrolled burning of MSW has caused air pollution problem for the surrounding environment. It is estimated that about $40-50 \%$ of MSW transported to open dumping sites are uncontrolled burnt.

\subsection{Community health impacts}

Inappropriate management of MSW not only causes the environmental impacts but also the community health impacts. The survey results showed that people living near the open dumping sites and unsanitary landfills are being exposed to the adverse impacts with the symptoms of dermatological disease, respiratory diseases, and diarrhea. The most vulnerable groups are scavengers in which most of them are women and children.

\subsection{Social-economic impacts}

During the last five years, the MSW quantity has been increasing significantly. As a consequence, the expenses used for collection, transportation, treatment and disposal have been increasing. In addition, there is the other expense required for treating environmental pollution associated with MSW.

On the other hand, there have been the environmental conflicts arisen from the inappropriate storage, transportation, treatment and disposal of MSW. The most popular environmental conflicts associated with MSW seen are those between pollution causing companies/enterprises and suffered community, social groups in handicraft villages, small-scale industry activities and agricultural activities, and production activities and landscape as well as culture.

\section{Current MSW management practices and challenges}

Different methods for the disposal and treatment of MSW being applied in Vietnam are summarized as follows:

\subsection{Open dumping and landfill}

Open dumping and landfill are the most popular method for MSW disposal in urban areas in Vietnam at present. It is estimated that the proportion of MSW disposed at open dumping sites and landfills accounting for $76-82 \%$ of the total collected MSW quantity. In the whole country, there are totally 98 open dumping sites and landfills in operation and most of them located in urban areas. In which, there are only 16 sanitary landfills and the remaining are open dumping sites and unsanitary landfills. However, the overloading status has occurred at many open dumping sites and landfills. Currently, open dumping sites and unsanitary landfills are dispersed in $80-85 \%$ of the total 755 cities and towns in Vietnam (MONRE, 2011). At these sites, MSW is directly disposed in an uncontrolled and poorly managed manner. Compaction and leveling of waste and final covering by earth are rarely observed practices at most disposal sites. In addition, these disposal sites are lack of a leachate collection system, protection at the bottom by a geo-membrane or clay-lined layer, and landfill gas monitoring and collection equipment giving rise to serious environmental degradation.

Besides the official disposal sites, many cities and towns are also being suffered from the illegal disposal of waste in rivers, lakes, oceans, drainage channels, empty lots and roadsides.

Although there are many environmental pollution problems associated with the disposal of MSW at open dumping and landfill sites, however, it appears that landfill would continue to be the most widely adopted practice in Vietnam in the coming few years, during which certain improvements will have to be made to ensure the sanitary landfill - an acceptable and recommended method for ultimate disposal of MSW.

\subsection{Composting}

The bacterial conversion of the organics present in MSW in the presence of air under hot and moist conditions is called composting, and the final product obtained after bacterial activity is called compost (humus), which has very high agricultural value. It is non-odorous and free of pathogens and can be used as fertilizer. As a result of the composting process, the waste volume can be reduced to $50-85 \%$. The composting methods may use either manual or mechanical means and are accordingly termed as a manual or mechanical process (Sharholy et al., 2008).

Manual composting method is usually carried out in small urban areas in Vietnam. With respect to mechanical composting method, there are several domestic technologies named SERAPHIN and ANSINH - ASC have been certified by the authorized agency and applied in waste treatment plants in the big cities of Ha Noi, Hue and provinces of Nghe An, Ha Nam. However, the composting efficiency at these waste treatment plants is not high since wastes are not separated at sources. At composting plants, the waste quantity generated after treatment which being disposed at landfill accounting for $35-40 \%$ of the waste quantity inputted to composting plants, although a large proportion of the input waste is organic waste.

Although known as a useful and cost-effective means for treatment of MSW, the proportion of MSW to be composted is not really high at present. It is estimated that with the operation at full capacity of all existing composting plants, the composted quantity of MSW is still smaller than 2,500 tons/day which is less than $10 \%$ total quantity of MSW generated (MONRE, 2011). In fact, most of composting plants are not operating at full capacity since there is a difficulty with the selling of composting products due to several reasons such as inadequate market survey 
prior to construction of the facilities, inadequate monitoring of the quality and quantity of the compost being produced, and lack of attention by the marketing organization to the distribution of the compost and to consumer feedback.

\subsection{Incineration}

Incineration is the process of control and complete combustion of solid wastes. The temperature in incinerators varies between $980-2000^{\circ} \mathrm{C}$. One of the most attractive features of incinerators is that it can be used to reduce the original volume of combustible solid waste by 80-90\%. In addition, energy generated from combustion can be recovered for other uses.

Unfortunately, in Vietnam, application of incineration for MSW treatment is not very much practiced. The major reason is the high investment cost required for incinerators. The other reasons might be the high organic materials and high moisture content in MSW which causes the difficulty for combustion process. There is only one large-scale MSW incinerator with a capacity of 300 tons/day installed in Son Tay town, Ha Noi City at present. As an effort to reduce the burden for landfills and the associated environmental pollution problems, Ha Noi and Ho Chi Minh are planning to import advanced incineration technology with heat recovery for power generation.

\subsection{Recycling}

Waste recycling has been successfully applied in many countries. A relatively large proportion of recyclable materials, for example paper, glass, plastic, rubber, and metals present in the MSW are suitable for recycling as seen in Table 2. However, the recycled MSW quantity just accounts for a small proportion, about $8-12 \%$ of the total collected recyclable MSW quantity at present. This is much lower than those in the Asian developed countries. For example, the recycling rate of metal and paper/cardboard in Singapore is $>85 \%$ and $40.3 \%$, respectively while the recycling rate of paper/cardboard in Japan is 55\% (Shekdar, 2009). One major component of MSW is plastics, widely used in the daily activities, has not been recycled to any satisfactory levels like those in other Asian countries where a wide range of products is made from recycled plastic including: polyethylene bin liners and carrier bags; PVC sewer pipes, flooring and window frames; building insulation board; video and compact disc cassette cases; fencing and garden furniture; water butts, garden sheds and composters; seed trays; fiberfill for sleeping bags and duvets; and a variety of office accessories (Ngoc and Schnitzer, 2009). Disposal of plastic products, by either landfill or incineration, has presented problems due to their slow decay in the natural environment or the release of toxic chemicals during combustion. The urgency to solve the problem of plastic waste in Vietnam therefore needs to be emphasized.

On the other hand, recycling practice is now mainly performed by the informal sector such as private companies, handicraft villages, and scavengers. However, recycling technologies used by private companies and handicraft villages are still traditional and backward, thus causing serious environmental pollution problems. Especially, there are many handicraft villages located inside the urban areas and thus potentially cause serious health impact problems. The role of governments in recycling practice is still small compared to that of the informal sectors. Similar to the cases of many developing countries, the role of the informal sector in MSW management in urban areas in Vietnam is also important because it provides a livelihood to many immigrants and marginalized people. In addition, the informal collection could avoid environmental costs and reduce capacity problems at dumping and landfill sites. Scavengers are also expected to provide excellent segregation of MSW as they collect the recyclable materials from the streets, bins and disposal sites for their livelihood.

\section{Conclusions and recommendations}

The recently rapid urbanization, industrialization and economic development have caused a significant increase of MSW generation in Vietnam. However, there is a lack of resources for MSW management such as finance, infrastructure, and manpower at present. The continuous increase of service demands combined with the lack of resources is putting a huge strain on the existing MSW management systems.

Currently, at the level of MSW generation and collection, there is no separation activity at source of compostable waste from the other non-biodegradable and recyclable waste. Thus proper implementation of source separation would lead to better options and opportunities for scientific disposal of waste.

It seems that waste minimization will continue to be one of the major challenges faced by Vietnam and needs to be implemented more strictly. At present, there is no limitation on the quantity of MSW that may be generated. The convenience of waste discarding, to a certain extent, is also responsible for the increasing MSW generation. It is therefore important to call for discipline and good social norms, and to frequently implement the environmental protection campaigns for raising the public awareness and self-consciousness with respect to MSW management.

A majority of the collected MSW quantity in Vietnamese urban areas is being disposed at open dumping sites and unsanitary landfills in an uncontrolled manner. Such unscientific disposal practices have led to adverse impacts on all components of environment, community health, and social-economic development. Thus it is necessary to upgrade the existing open dumping sites and unsanitary landfills to sanitary landfill in a phased manner. Landfill should be restricted to non-biodegradable, inert waste and other waste that are not suitable either for recycling or for biological processing.

Composting has become more popular in Vietnam. However, in order to make the application of this technology to be successful, a stable market for the 
processed products must be secured by performing a number of activities such as market survey, monitoring of the quality and quantity of the compost being produced.

Although incineration is well-known as advanced technology for treatment of MSW, its application is still limited at present. Incineration therefore should be given more investment in the coming years. This will help to reduce the burden of largely disposed MSW volume facing by the landfills.

Clearly, promotion and development of recycling is a means for upgrading the living and working conditions of scavengers and other marginalized groups. In addition, it will contribute in saving of valuable raw material resources of country, reducing the need for landfill space, a less energy-intensive way to produce some products and employing labor in recycling industries. It is essential that governments and responsible agencies should play more important roles, such as organizing the informal sector and promoting micro-enterprises in an effective way for extending affordable services.

\section{References}

Ministry of Natural Resource and Environment (MONRE). 2011. National Environment Report 2011 (in Vietnamese).

Mufeed, S., Ahmad, K., Mahmood, G., Trivedi, R.C. 2008. Municipal solid waste management in Indian cities - A review. Waste Management $28,459-467$.

Ngoc, U.N., and Schnitzer, H. 2009. Sustainable solutions for solid waste management in Southeast Asian countries. Waste Management 29, 1982-1995.

Shekdar, A.V. 2009. Sustainable solid waste management: An integrated approach for Asian countries. Waste Management 29, 1438-1448.

Thanh, N.P. 2010. Household solid waste generation and characteristic in Mekong Delta city, Vietnam. Journal of Environmental Management 91 (11), 2307-2321.

Thanh, N.P. 2011. Assessment of plastic waste generation and its potential recycling of household solid waste in Can Tho City, Vietnam. Environmental Monitoring and Assessment 175 (1-4), 23-35. 